\title{
The FDA Unapproved Drugs Initiative: An Observational Study of the Consequences for Drug Prices and Shortages in the United States
}

\author{
Ravi Gupta, MD; Sanket S. Dhruva, MD; Erin R. Fox, PharmD; and Joseph S. Ross, MD, MHS
}

\begin{abstract}
BACKGROUND: Hundreds of drug products are currently marketed in the United States without approval from the FDA. The 2006 Unapproved Drugs Initiative (UDI) requires manufacturers to remove these drug products from the market or obtain FDA approval by demonstrating evidence of safety and efficacy. Once the FDA acts against an unapproved drug, fewer manufacturers remain in the market, potentially enabling drug price increases and greater susceptibility to drug shortages. There is a need for systematic study of the UDI's effect on prices and shortages of all targeted drugs.
\end{abstract}

OBJECTIVE: To examine the clinical evidence for approval and association with prices and shortages of previously unapproved prescription drugs after being addressed by the UDI.

METHODS: Previously unapproved prescription drugs that faced UDI regulatory action or with at least 1 product that received FDA approval through manufacturers' voluntary compliance with the UDI between 2006 and 2015 were identified. The clinical evidence was categorized as either newly conducted clinical trials or use of previously published literature and/or bioequivalence studies to demonstrate safety and efficacy. We determined the change in average wholesale price, presence of shortage, and duration of shortage for each drug during the 2 years before and after UDI regulatory action or approval through voluntary compliance.

RESULTS: Between 2006 and 2015, 34 previously unapproved prescription drugs were addressed by the UDI. Nearly $90 \%$ of those with a drug product that received FDA approval were supported by literature reviews or bioequivalence studies, not new clinical trial evidence. Among the 26 drugs with available pricing data, average wholesale price during the 2 years before and after voluntary approval or UDI action increased by a median of $37 \%$ (interquartile range [IQR] $=23 \%-204 \% ; P<0.001)$. The number of drugs in shortage increased from $17(50.0 \%)$ to $25(73.5 \%)$ during the 2 years before and after, respectively $(P=0.046)$. The median shortage duration in the 2 years before and after voluntary approval or UDI action increased from 31 days (IQR $=0-339)$ to 217 days (IQR $=0-406 ; P=0.053)$.

CONCLUSIONS: The UDI was associated with higher drug prices and more frequent drug shortages when compared with the period before UDI action, while the approval process for these drugs did not necessarily require new clinical evidence to establish safety or efficacy.

J Manag Care Spec Pharm. 2017;23(10):1066-76

Copyright $\odot 2017$, Academy of Managed Care Pharmacy. All rights reserved.

\section{What is already known about this subject}

There are hundreds of drug products currently marketed in the United States without approval from the FDA.

To ensure the safety and efficacy of previously unapproved drug products, the FDA's 2006 Unapproved Drugs Initiative (UDI) requires manufacturers to remove these drug products from the market or obtain FDA approval.

There are concerns that the UDI may increase the price of specific drugs by unintentionally reducing the number of manufacturers.

\section{What this study adds}

Systematic review of all prescription drugs targeted by the UDI between 2006 and 2015 showed that the price of these drugs increased by a median of $37 \%$ after UDI regulatory action or approval.

The number of drugs in shortage increased from 17 (50\%) to 25 (74\%) during the 2 years before and after UDI regulatory action or approval, and the median shortage duration increased from 31 days to 217 days.

Nearly $90 \%$ of previously unapproved drugs with a drug product that received FDA approval through the UDI were supported by literature reviews or bioequivalence studies, not new clinical trial evidence.

$\mathrm{H}$ undreds of drug products are currently marketed in the United States without having first received approval from the U.S. Food and Drug Administration (FDA). Most of these drugs are decades old and available largely as an unintended consequence of early legislation. ${ }^{1}$ The 1938 Food, Drug, and Cosmetic Act required manufacturers of new drugs to provide evidence of safety, but not efficacy, to the FDA for approval. In 1962, the Kefauver-Harris Amendments broadened the FDA's authority, establishing requirements to also provide evidence of efficacy for FDA approval. To retrospectively determine the efficacy of drugs approved only on the basis of safety evidence between 1938 and 1962, the Kefauver-Harris Amendments established the Drug Efficacy Study Implementation (DESI) review, requiring market withdrawal of drug products found to be inefficacious. ${ }^{2,3}$ While over 3,400 drug products were evaluated through this process, many without FDA approval still remained on the market. Most of these unapproved drugs were originally introduced 
before 1938, while others were originally introduced between 1938 and 1962, but the manufacturer did not comply with the DESI review decision. ${ }^{4}$

Although manufacturers were expected to obtain approval for unapproved drug products or withdraw them from the market, their persistent market availability led the FDA to enact the Unapproved Drugs Initiative (UDI) in 2006. The FDA developed a plan to require either the approval of unapproved drug products or their removal from the market through issuance of warning letters or, in some cases, a "seizure, injunction, or other proceeding." In some instances, these warning letters are sent to individual manufacturers of a drug product, while in other cases, blanket Federal Register Notices are issued to all manufacturers of drug products containing specific unapproved active ingredients. For example, in 2007 the FDA issued a Federal Register Notice to all manufacturers of any unapproved drug products containing hydrocodone bitartrate or any other salt or ester of hydrocodone, including cough suppressants and pain relievers. ${ }^{5}$ Between 2006 and 2015, the UDI targeted 34 drug classes, which are referred to throughout this study simply as "drugs." In contrast, we refer to specific manufacturers' drugs as "drug products" or just "products."

While the FDA attempts to actively identify unapproved drug products marketed in the United States, these drugs are occasionally brought to its attention through reports of safety issues, ineffectiveness, health fraud, and compliance inspections. ${ }^{4}$ The UDI directs the FDA to employ a risk-enforcement approach, prioritizing drugs that pose greater risks from lack of safety or efficacy. The FDA also continues to rely on compliance efforts from manufacturers who voluntarily obtain FDA approval for their previously unapproved drug products.

Although the FDA has taken regulatory action on more than 500 unapproved drug products through the UDI, hundreds more still exist as different dosages, formulations, and combinations. ${ }^{4}$ The FDA estimated that approximately $2 \%$ of all prescriptions dispensed in the United States in 2006 may have been for drug products lacking FDA approval. ${ }^{6}$ Sublingual nitroglycerin provides an illustrative example. Used by millions of patients for relief of angina, the drug was marketed until 2010 by multiple manufacturers without approval; $80 \%$ of nearly 4.4 million prescriptions for sublingual nitroglycerin in 2009 were for drug products that never received FDA approval. ${ }^{7}$

While the UDI benefits public health by ensuring marketed drugs have demonstrated safety and efficacy, it may also have unintended consequences. Once the FDA takes action against an unapproved drug, fewer manufacturers remain in the market, potentially enabling drug price increases and greater susceptibility to drug shortages. Previous articles have explored the historical background for the $\mathrm{UDI}^{3,8,9}$ and characterized the experience of individual unapproved drugs, ${ }^{3,8-12}$ including the finding that prices and shortages of specific drugs increased after they were targeted by the UDI. ${ }^{13-17}$ However, to understand whether these individual examples are emblematic of a fundamental problem with the design of the UDI, there is a need for the systematic study of the changes in prices and shortages of all previously unapproved drugs targeted by the UDI. Understanding the effects of FDA policies on drug prices and shortages, particularly at a time when both are already increasing markedly overall, ${ }^{18-22}$ is important in ensuring continued patient access to these drugs.

Our objective was to identify previously unapproved prescription drugs that faced FDA UDI regulatory action or had at least 1 product that received FDA approval between 2006 and 2015 through voluntary compliance with the UDI. We then sought to compare prices and the presence and duration of shortages for these drugs before and after UDI action or approval after voluntary compliance, while also characterizing the clinical evidence used to support the approvals for the affected drugs.

\section{Methods}

\section{Study Sample}

We constructed a sample of previously unapproved prescription drugs that between 2006 and 2015 either (a) faced UDI regulatory action or (b) had at least 1 product that received FDA approval through manufacturers' voluntary compliance with the UDI; we excluded previously unapproved over-thecounter drugs because they are subject to a different FDA review process.

Previously unapproved drugs facing UDI regulatory action were identified through review of a publicly accessible database of all FDA enforcement actions since 2006. ${ }^{23}$ Previously unapproved drugs with at least 1 product that received approval through a manufacturer's voluntary compliance were identified from Drugs@FDA, a publicly accessible database that provides a comprehensive listing of approved drug products. This database was used to identify New Drug Applications (NDAs) for drug products previously "marketed without an approved NDA." 24 Some drugs had a product labeled as previously "marketed without an approved NDA" and also faced UDI regulatory action. In these cases, if the drug had at least 1 product that received NDA approval with such a label before regulatory action, it was categorized as a voluntary approval. If the drug received all such NDA approvals after regulatory action, it was categorized as having faced UDI regulatory action.

\section{Clinical Evidence}

For all drugs with at least 1 product that received approval between 2006 and 2015 either after UDI enforcement action or through voluntary compliance, we characterized the clinical evidence supporting approval. The clinical evidence was categorized as either newly conducted clinical trials or use of previously published literature and/or bioequivalence studies to demonstrate safety and efficacy. This information was 
determined by reviewing each drug product's NDA approval documents available at Drugs@FDA. For previously unapproved drugs with a product that received approval through voluntary compliance, we reviewed the specific drug manufacturer's NDA approval documents. For drugs facing UDI regulatory action, we reviewed the NDA approval documents of the first manufacturer to obtain approval after the date of UDI regulatory action; abbreviated NDA documents were not reviewed since they are for approval of generic drugs, which must only demonstrate bioequivalence to their NDA counterparts.

\section{U.S. Drug Prices}

We determined the change in average price for each drug during the 2 years before and after UDI regulatory action or approval through voluntary compliance using drugs' average wholesale prices from Micromedex's RED BOOK database. ${ }^{25}$ For each drug, we identified the manufacturer of the product with the lowest average wholesale price in the 2 years before voluntary approval or UDI action and with the most complete data among all manufacturers (i.e., with listed prices each year). This drug product was used as a representative for each of the 34 drug classes. We used unit prices, which are per gram, per milliliter, or per piece (e.g., pill), because some drugs in our sample are consumed daily, whereas others are taken as needed. When the selected drug product's manufacturer did not list the price in certain years, we determined the price of the cheapest drug product of the same dose from a different manufacturer. Thus, for example, if the FDA required UDI compliance for a drug in 2009, and only 1 manufacturer had a price listed in 2007 and 2008, but the same manufacturer had no price listed in either 2010 or 2011, we determined the lowest listed price in 2010 and 2011 of a different manufacturer.

To identify the before and after time point for drugs where at least 1 product was approved voluntarily, we used the year of approval, whereas for drugs facing UDI action, we used the compliance date stated in the warning letters, since in the time between the warning letter or federal notice issuance and compliance date, some manufacturers may have discontinued unapproved drug products, while others may have received approval for previously unapproved drug products. When a drug was categorized as "voluntary compliance" because at least 1 drug product was approved before UDI enforcement action, but other manufacturers subsequently faced UDI action for their drug products, we used the date of the UDI warning letter or federal notice compliance.

In addition, where available, we identified the specific manufacturers to which the FDA sent UDI warning letters or that were labeled as previously "marketed without an approved NDA" in Drugs@FDA. We used the RED BOOK to examine the price changes immediately before and after the date that these specific manufacturers faced regulatory action or obtained approval for the drug products.

\section{U.S. Drug Shortages}

We used the University of Utah's Drug Information Service drug shortage database from January 1, 2004, to December 31, 2015. A shortage is defined as a supply issue that affects how a pharmacy prepares or dispenses a drug product that influences patient care when prescribers must use an alternative agent. ${ }^{26}$ The Drug Information Service receives voluntary reports of drug shortages, which are confirmed by clinical pharmacists, who contact all manufacturers of a reported drug to determine if there is a national shortage. A shortage is considered resolved when all manufacturers have all drug products available, have discontinued their products, or the FDA reports on its website that the shortage has been resolved. ${ }^{27}$

For each of the 34 drugs included in the sample, we determined whether there was a shortage during the 2 years before and after the date of UDI regulatory action or approval through voluntary compliance. For before and after this date, if there was a shortage, we determined the median duration of the shortage in days for each drug. Shortages lasting fewer than 7 days were excluded from the calculation of shortage duration because these shortages signify in the database that, although the drug is in shortage, it was withdrawn from the market, and thus the true shortage end date cannot be determined. To identify the before and after time point for drugs where at least 1 product was approved voluntarily, we used the year of approval, whereas for drugs facing UDI action (since a shortage could ensue immediately after a manufacturer discontinued the drug), we used the date that the warning letter or federal notice was issued. For drugs where a product was approved through a manufacturer's voluntary compliance and other manufacturers subsequently faced UDI action for their drug products, we used the issue date of the UDI warning letter or federal notice. For each drug, if multiple shortages reported by different manufacturers overlapped in time, they were counted as only one. For the presence of shortage analysis only, each shortage was attributed to the year in which the shortage was active. For example, if a shortage lasted from October 2009 to March 2011, it was counted for the years 2009, 2010, and 2011.

\section{Statistical Analysis}

We used descriptive statistics to characterize the sample of included drugs and the clinical evidence that supported applications for drugs approved after 2006 through either voluntary compliance or after issuance of UDI warning letters or federal notices. We used nonparametric signed rank sum tests to compare changes in prices and duration of shortages and $\chi 2$ tests to compare changes in the presence of shortages. All statistical tests were 2 -sided and used a $P$ value of 0.05 for significance. All analyses were performed using Microsoft Excel 2010 (Microsoft Corp., Redmond, WA) and Stata version 12.0 (StataCorp, College Station, TX). 
The FDA Unapproved Drugs Initiative: An Observational Study

of the Consequences for Drug Prices and Shortages in the United States

\section{FIGURE 1 Sample Construction of Previously Unapproved Prescription Drugs that Faced UDI Regulatory} Action or Had at Least 1 Product that Received Voluntary Approval After 2006

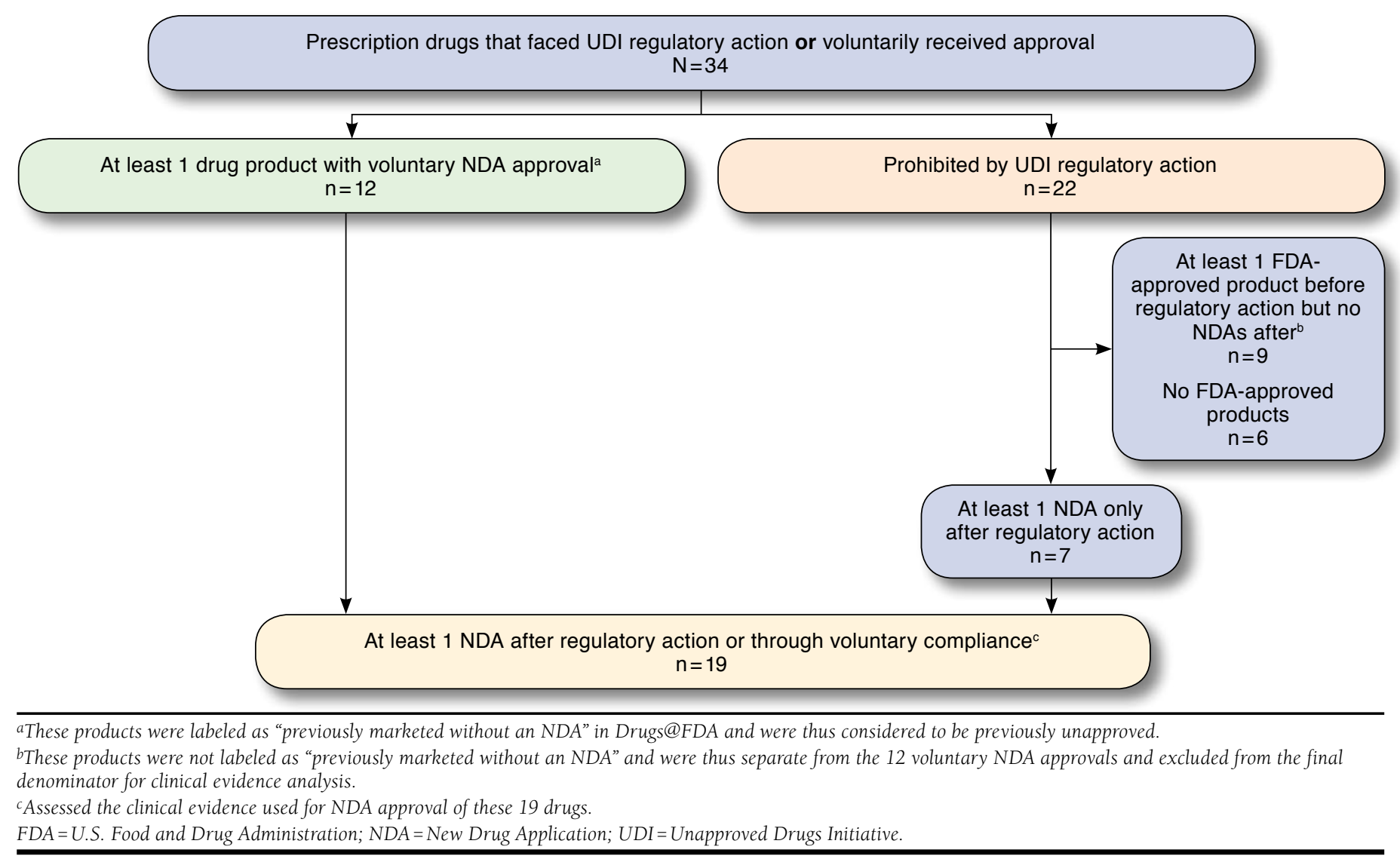

\section{Results}

\section{Characteristics of All Drugs Facing UDI Action}

Since the UDI was launched in 2006, 12 previously unapproved prescription drugs had at least 1 product that received FDA approval through voluntary compliance (i.e., labeled as "previously marketed without an NDA" in Drugs@FDA), whereas 22 faced UDI regulatory action, for a total of 34 drugs included in our study (Figure 1). Of the 22 drugs facing UDI action, 6 had no FDA-approved products as of September 1, 2016, either before or after UDI action; 9 drugs had at least 1 product that was approved but not labeled as "previously marketed without an NDA" before UDI action and no NDAapproved products after; and the remaining 7 drugs had at least 1 NDA-approved product only after UDI action.

Of the 34 drugs, 22 (64.7\%) were first introduced into the U.S. market before the Food, Drug, and Cosmetic Act in 1938 (Table 1), and the 34 drugs are used for a range of primary indications, including 11 (32.4\%) for pain control, 6 (17.6\%) for ophthalmic solutions, and 4 (11.8\%) for management of upper respiratory symptoms or allergies.

\section{Clinical Evidence of Safety and Efficacy}

Nineteen drugs had at least 1 product with NDA approval after 2006 (Figure 1), either after UDI action or as part of voluntary compliance. Evidence provided in the NDA to support efficacy (Table 2) was based on a newly conducted clinical trial for $2(10.5 \%)$ drugs, a literature review for $6(31.6 \%)$ drugs, demonstrated bioequivalence to a previously approved drug product with the same active ingredient for 6 (31.6\%) drugs, and a literature review and demonstrated bioequivalence to previous drug products for 5 (26.3\%) drugs. A similar pattern was observed for the evidence provided in the NDA to support safety.

\section{Association Between the UDI and Drug Prices}

Of the 34 drugs facing UDI action or with a product receiving approval through voluntary compliance, 26 had at least 1 product with prices listed in the RED BOOK during the 2 years before and after UDI action or voluntary approval. Among these 26 drugs, the product with the lowest average price during the 2 years before and after UDI action or voluntary 
The FDA Unapproved Drugs Initiative: An Observational Study

of the Consequences for Drug Prices and Shortages in the United States

\section{TABLE 1 Characteristics of Previously Unapproved Drugs Facing UDI Regulatory Action}

or Receiving Voluntary Approval $(\mathrm{N}=34)$

\begin{tabular}{|c|c|c|c|c|}
\hline Drug & $\begin{array}{c}\text { Year of First } \\
\text { Market } \\
\text { Availabilitya }\end{array}$ & Primary FDA-Approved Indications & $\begin{array}{c}\text { Voluntary } \\
\text { Compliance } \\
\text { or Regulatory } \\
\text { Action }\end{array}$ & $\begin{array}{c}\text { Year of } \\
\text { Voluntary } \\
\text { Compliance } \\
\text { or Regulatory } \\
\text { Action }\end{array}$ \\
\hline Atropine sulfate ophthalmic solution & Before 1938 & Cycloplegia, pupillary dilation, ambylopia & Voluntary & 2014 \\
\hline Balanced salt solution (ophthalmic) & $1960 \mathrm{~s}$ & Eye fluid replacement during surgical procedures & Regulatory & 2008 \\
\hline Carbinoxamine & Early 1950 s & Seasonal and perennial allergic rhinitis, vasomotor rhinitis & Regulatory & 2006 \\
\hline Codeine phosphate combinations & Before 1938 & $\begin{array}{l}\text { Cough, symptoms of upper respiratory allergies or common } \\
\text { cold }\end{array}$ & Regulatory & 2014 \\
\hline Codeine phosphate injection & Before 1938 & Mild to moderately severe pain in adults & Regulatory & 2014 \\
\hline Codeine sulfate tablet & Before 1938 & Mild to moderately severe pain in adults & Voluntary & 2009 \\
\hline Colchicine injection & Before 1962 & Acute gout attacks & Regulatory & 2008 \\
\hline Colchicine tablet & Before 1938 & Gout flares & Voluntary & 2009 \\
\hline Dihydrocodeine bitartrate combinations & Before 1938 & Mild to moderately severe pain in adults & Regulatory & 2014 \\
\hline Epinephrine injection/syringe & Before 1938 & Allergic reactions, anaphylaxis & Regulatory & 2010 \\
\hline Ergotamine-containing product & Before 1938 & Vascular headaches, migraine & Regulatory & 2007 \\
\hline Fluorescein injection & Before 1938 & $\begin{array}{l}\text { Diagnostic fluorescein angiography, angioscopy of retina and } \\
\text { iris vasculature }\end{array}$ & Regulatory & 2012 \\
\hline Freshkote ophthalmic solution & Unknown & Dry eye & Regulatory & 2012 \\
\hline Hydrocodone & Before 1938 & Cough, pain & Regulatory & 2007 \\
\hline Hydromorphone injection & Before 1938 & Management of pain where opioid analgesic is appropriate & Voluntary & 2011 \\
\hline Hydromorphone tablet & Before 1938 & Management of pain where opioid analgesic is appropriate & Regulatory & 2009 \\
\hline Levothyroxine injection & Early 1960s & Myxedema coma & Regulatory & 2006 \\
\hline $\begin{array}{l}\text { Morphine sulfate immediate-release } \\
\text { tablet }\end{array}$ & Before 1938 & $\begin{array}{l}\text { Moderate to severe acute and chronic pain where opioid } \\
\text { analgesic is appropriate }\end{array}$ & Voluntary & 2008 \\
\hline Morphine sulfate injection & Before 1938 & Pain not responsive to non-narcotic analgesics & Voluntary & 2011 \\
\hline Morphine sulfate solution & Before 1938 & $\begin{array}{l}\text { Moderate to severe acute and chronic pain in opioid-tolerant } \\
\text { patients }\end{array}$ & Voluntary & 2008 \\
\hline Nitroglycerin sublingual tablet & Before 1938 & $\begin{array}{l}\text { Acute relief of an attack or acute prophylaxis of angina } \\
\text { pectoris due to coronary artery disease }\end{array}$ & Regulatory & 2010 \\
\hline Otic drugs & Unknown & Ear pain, infection, and inflammation & Regulatory & 2015 \\
\hline Oxycodone immediate-release tablet & 1939 & $\begin{array}{l}\text { Acute and chronic moderate to severe pain when use of } \\
\text { opioid analgesic is appropriate }\end{array}$ & Regulatory & 2009 \\
\hline Oxycodone solution & 1939 & Moderate to severe pain in opioid-tolerant patients & Voluntary & 2010 \\
\hline Pancrelipase & Before 1938 & $\begin{array}{l}\text { Exocrine pancreatic insufficiency due to cystic fibrosis or } \\
\text { other conditions }\end{array}$ & Regulatory & 2010 \\
\hline Papain-containing topical drug & Before 1962 & $\begin{array}{l}\text { Debridement of necrotic tissue, liquefaction of slough in } \\
\text { acute and chronic lesions }\end{array}$ & Regulatory & 2008 \\
\hline $\begin{array}{l}\text { Phenylephrine hydrochloride } \\
\text { (IV solution) }\end{array}$ & Before 1938 & Increase blood pressure in acute hypotensive states & Voluntary & 2012 \\
\hline $\begin{array}{l}\text { Phenylephrine hydrochloride } \\
\text { (ophthalmic solution) }\end{array}$ & Before 1938 & Pupillary dilation & Voluntary & 2013 \\
\hline $\begin{array}{l}\text { Pilocarpine hydrochloride ophthalmic } \\
\text { solution }\end{array}$ & Before 1938 & Reduction of elevated intraocular pressure, glaucoma & Regulatory & 2012 \\
\hline Potassium chloride oral solution & Before 1962 & Hypokalemia & Voluntary & 2014 \\
\hline Quinine & Before 1938 & Uncomplicated Plasmodium falciparum malaria & Regulatory & 2007 \\
\hline $\begin{array}{l}\text { Sodium nitrite and sodium thiosulfate } \\
\text { injection }\end{array}$ & Before 1962 & Cyanide poisoning & Regulatory & 2013 \\
\hline $\begin{array}{l}\text { Trimethobenzamide hydrochloride } \\
\text { suppository }\end{array}$ & Before 1962 & Nausea and vomiting & Regulatory & 2007 \\
\hline Vasopressin & Before 1938 & Vasodilatory shock & Voluntary & 2014 \\
\hline
\end{tabular}

aFor many drugs, the date of first availability could not be found.

FDA =U.S. Food and Drug Administration; IV=intravenous; UDI = Unapproved Drugs Initiative. 
TABLE 2 Clinical Evidence Supporting NDA Approval of Prescription Drugs After Facing UDI Regulatory Action or Receiving Voluntary Approval $(N=19)^{a}$

\begin{tabular}{|c|c|c|}
\hline Drug & Efficacy Evidence & Safety Evidence \\
\hline $\begin{array}{l}\text { Atropine sulfate ophthalmic } \\
\text { solution }\end{array}$ & $\begin{array}{l}\text { Literature review of } 57 \text { studies from 1931-2013; } 8 \text { studies } \\
\text { summarized in application ( } 3 \text { randomized, } 2 \text { double-blind, } \\
\text { average } 173 \text { subjects) }\end{array}$ & $\begin{array}{l}\text { Literature review and statement of long history and frequent } \\
\text { use }\end{array}$ \\
\hline Carbinoxamine & $\begin{array}{l}2 \text { bioequivalence studies; reviewed } 4 \text { studies from } 1954- \\
1956 \text { ( } 2 \text { placebo-controlled, average } 105 \text { subjects) involved } \\
\text { in DESI review of initial carbinoxamine product }\end{array}$ & $\begin{array}{l}\text { Safety events from } 2 \text { bioequivalence studies; reviewed side } \\
\text { effects in } 4 \text { studies from 1954-1956 from DESI review }\end{array}$ \\
\hline $\begin{array}{l}\text { Codeine phosphate } \\
\text { combinations }\end{array}$ & 2 bioequivalence studies & $\begin{array}{l}2 \text { bioequivalence studies; summary of data from } 2 \text { clinical } \\
\text { pharmacology studies, postmarketing spontaneous adverse } \\
\text { events report, and a literature survey }\end{array}$ \\
\hline Codeine sulfate tablet & $\begin{array}{l}5 \text { bioequivalence studies, literature review of } 159 \text { studies; } \\
6 \text { studies from 1970-1978 used to support approval (all } \\
\text { randomized, double-blind, placebo-controlled, average } 127 \\
\text { subjects) }\end{array}$ & $\begin{array}{l}\text { Based on safety reported in labeling of reference product } \\
\text { (codeine in Tylenol \#3) }\end{array}$ \\
\hline Colchicine tablet & $\begin{array}{l}\text { Conducted clinical trial (randomized, double-blind, placebo- } \\
\text { controlled, l-week-long, } 185 \text { subjects); referenced l clinical } \\
\text { trial from } 1987 \text { in published literature (randomized, double- } \\
\text { blind, placebo-controlled, } 43 \text { subjects) }\end{array}$ & $\begin{array}{l}\text { Conducted clinical trial; data from } 14 \text { pharmacokinetic } \\
\text { studies (total } 314 \text { subjects); literature review ( } 3 \text { randomized } \\
\text { controlled studies and } 21 \text { uncontrolled studies); review of } \\
\text { FDA and World Health Organization postmarketing adverse } \\
\text { event report databases }\end{array}$ \\
\hline $\begin{array}{l}\text { Epinephrine } \\
\text { injection/syringe }\end{array}$ & $\begin{array}{l}\text { Recommended dosing based on published literature and } \\
\text { established clinical practice; based on previous findings for } \\
\text { epinephrine in treatment of allergic reactions and anaphy- } \\
\text { laxis }\end{array}$ & $\begin{array}{l}\text { Based on previous findings for epinephrine in treatment of } \\
\text { allergic reactions and anaphylaxis }\end{array}$ \\
\hline Hydrocodone & 1 bioequivalence study; literature review & $\begin{array}{l}1 \text { bioequivalence study; literature review ( } 5 \text { studies); review of } \\
\text { adverse events reporting system database }\end{array}$ \\
\hline Hydromorphone injection & None based on prior approval of hydromorphone products & None; based on prior approval of hydromorphone products \\
\hline Levothyroxine injection & $\begin{array}{l}\text { Literature review of } 45 \text { studies from 1953-2007 (1 open- } \\
\text { label trial involving } 14 \text { subjects) }\end{array}$ & $\begin{array}{l}\text { Literature review of } 40 \text { studies from 1964-2004 (1 open-label } \\
\text { trial involving } 14 \text { subjects) }\end{array}$ \\
\hline $\begin{array}{l}\text { Morphine sulfate } \\
\text { immediate-release tablet }\end{array}$ & 3 bioequivalence studies & 3 bioequivalence studies \\
\hline Morphine sulfate injection & $\begin{array}{l}\text { Previous findings for reference product but no bioequiva- } \\
\text { lence studies; literature review of } 59 \text { studies involving ran- } \\
\text { domized controlled trials }\end{array}$ & $\begin{array}{l}\text { Previous findings for reference product but no bioequivalence } \\
\text { studies; literature review of } 59 \text { studies involving randomized } \\
\text { controlled trials }\end{array}$ \\
\hline Morphine sulfate solution & 1 bioequivalence study & Previous findings from reference product \\
\hline $\begin{array}{l}\text { Oxycodone immediate- } \\
\text { release tablet }\end{array}$ & 2 bioequivalence studies; literature review of 10 studies & 2 bioequivalence studies; literature review of 10 studies \\
\hline Oxycodone solution & 1 bioequivalence study & 1 bioequivalence study \\
\hline Pancrelipase & $\begin{array}{l}1 \text { clinical trial (randomized, double-blind, placebo-con- } \\
\text { trolled, length of } 2 \text { weeks, } 32 \text { subjects); literature review of } \\
15 \text { randomized, double-blind, placebo-controlled studies } \\
\text { (average } 40 \text { subjects, } 23 \text { days in length) }\end{array}$ & $\begin{array}{l}1 \text { clinical trial (randomized, double-blind, placebo-controlled } \\
\text { length of } 2 \text { weeks, } 32 \text { subjects) }\end{array}$ \\
\hline $\begin{array}{l}\text { Phenylephrine } \\
\text { hydrochloride (IV solution) }\end{array}$ & $\begin{array}{l}\text { Literature review only; no review of protocols, study reports, } \\
\text { datasets, case reports, or site visit; however, approved based } \\
\text { on generally consistent conclusions overall }\end{array}$ & $\begin{array}{l}\text { Literature review; review of pharmacovigilance database; } \\
\text { review of spontaneous reporting system and adverse event } \\
\text { reporting system databases }\end{array}$ \\
\hline $\begin{array}{l}\text { Phenylephrine hydrochloride } \\
\text { (ophthalmic solution) }\end{array}$ & $\begin{array}{l}\text { Literature review of } 5 \text { studies from 1967-2004 (average } 24 \\
\text { subjects) }\end{array}$ & $\begin{array}{l}\text { Literature review of } 25 \text { studies from 1939-2010 ( } 8 \text { clinical } \\
\text { trials, average } 52 \text { subjects) }\end{array}$ \\
\hline $\begin{array}{l}\text { Potassium chloride oral } \\
\text { solution }\end{array}$ & $\begin{array}{l}\text { Previous findings for reference product, but no bioequiva- } \\
\text { lence studies; literature review }\end{array}$ & $\begin{array}{l}\text { Previous findings for reference product but no bioequivalence } \\
\text { studies; literature review }\end{array}$ \\
\hline Vasopressin & $\begin{array}{l}\text { Literature review of } 19 \text { studies from 1997-2012 (11 random- } \\
\text { ized, } 8 \text { double-blind, average } 62 \text { patients) }\end{array}$ & $\begin{array}{l}\text { Literature review of } 19 \text { studies from 1997-2012 (average } 42 \\
\text { subjects) }\end{array}$ \\
\hline
\end{tabular}

${ }^{a}$ Clinical evidence was reviewed for the first NDA-approved drug product after 2006 through either voluntary compliance or after issuance of UDI warning letters. DESI=Drug Efficacy Study Implementation; FDA=U.S. Food and Drug Administration; IV=intravenous; NDA = New Drug Application; UDI =Unapproved Drugs Initiative

approval increased by a median of 37\% (interquartile range $[\mathrm{IQR}]=23 \%-204 \% ; P<0.001$; Table 3).

In addition, we identified prices for 10 drugs where specific drug product manufacturers were sent FDA UDI warning letters or were labeled as previously "marketed without an approved NDA." The prices of these 10 drug products increased from immediately before obtaining approval to immediately after by a median of $122 \%$ (IQR $=10 \%-351 \% ; P=0.013)$. 


\section{TABLE 3 Average Wholesale Unit Price of Previously Unapproved Prescription Drugs 2 Years Before and After UDI Regulatory Action or Voluntary Approval $(\mathrm{N}=26)$ and Unit Price of Specific Manufacturers' Drug Products Immediately Before and After ( $N=10)^{a, b}$}

\begin{tabular}{|c|c|c|c|c|c|c|c|}
\hline & $\begin{array}{c}\text { Year of UDI } \\
\text { Compliance } \\
\text { or Voluntary } \\
\text { Approval }\end{array}$ & $\begin{array}{l}\text { Unit Price } \\
\text { Before, } \$\end{array}$ & $\begin{array}{l}\text { Unit Price } \\
\text { After, } \$\end{array}$ & $\begin{array}{l}\text { Change in } \\
\text { Unit Price, \% }\end{array}$ & $\begin{array}{c}\text { Manufacturer } \\
\text { Unit Price } \\
\text { Before, } \$\end{array}$ & $\begin{array}{c}\text { Manufacturer } \\
\text { Unit Price } \\
\text { After, \$ }\end{array}$ & $\begin{array}{l}\text { Change in } \\
\text { Unit Price, \% }\end{array}$ \\
\hline Overall, median (IQR) & & $\begin{array}{c}0.74 \\
(0.23-2.63) \\
\end{array}$ & $\begin{array}{c}1.24 \\
(0.46-6.20) \\
\end{array}$ & $\begin{array}{c}37 \\
(23-157) \\
\end{array}$ & $\begin{array}{c}1.51 \\
(0.57-2.98) \\
\end{array}$ & $\begin{array}{c}4.05 \\
(1.01-14.40) \\
\end{array}$ & $\begin{array}{c}122 \\
(10-351) \\
\end{array}$ \\
\hline$P$ value & & & & $<0.001$ & & & 0.013 \\
\hline \multicolumn{8}{|l|}{ Drug } \\
\hline Atropine sulfate ophthalmic solution & 2014 & 3.42 & 3.88 & 13.3 & 2.22 & 6.35 & 186.6 \\
\hline Balanced salt solution (ophthalmic) & 2008 & 0.17 & 0.18 & 6.1 & - & - & - \\
\hline Codeine phosphate combinations & 2014 & 0.80 & 1.11 & 37.8 & - & - & - \\
\hline Codeine sulfate tablet & 2010 & 0.43 & 0.46 & 5.8 & - & - & - \\
\hline Colchicine tablet & 2010 & 0.33 & 5.82 & $1,663.6$ & 0.17 & 5.82 & $3,323.5$ \\
\hline Dihydrocodeine bitartrate combinations & 2014 & 2.63 & 3.36 & 27.8 & - & - & - \\
\hline Epinephrine injection/syringe & 2010 & 0.49 & 1.15 & 136.2 & 1.44 & 2.28 & 58.3 \\
\hline Ergotamine-containing product & 2007 & 107.38 & 138.60 & 29.1 & 1.58 & 1.89 & 19.6 \\
\hline Fluorescein injection & 2012 & 6.60 & 8.94 & 35.5 & - & - & - \\
\hline Hydrocodone & 2007 & 0.20 & 0.26 & 26.2 & - & - & - \\
\hline Hydromorphone injection & 2011 & 1.20 & 1.34 & 11.7 & 1.10 & 1.01 & -8.7 \\
\hline Hydromorphone tablet & 2009 & 0.67 & 0.85 & 26.8 & - & - & - \\
\hline Levothyroxine injection & 2006 & 7.20 & 18.00 & 150.0 & 50.93 & 180.00 & 253.4 \\
\hline Morphine sulfate immediate-release tablet & 2009 & 0.18 & 0.20 & 9.3 & - & - & - \\
\hline Morphine sulfate injection & 2011 & 0.23 & 0.59 & 154.3 & 0.47 & 0.48 & 2.1 \\
\hline Morphine sulfate solution & 2010 & 0.08 & 0.08 & 4.5 & - & - & - \\
\hline Nitroglycerin sublingual tablet & 2010 & 0.15 & 0.19 & 23.3 & - & - & - \\
\hline Oxycodone immediate-release tablet & 2009 & 0.35 & 0.80 & 128.6 & 0.57 & 0.61 & 7.0 \\
\hline Oxycodone solution & 2010 & 1.15 & 5.55 & 382.6 & - & - & - \\
\hline Pancrelipase & 2010 & 0.46 & 0.70 & 51.1 & - & - & - \\
\hline Phenylephrine hydrochloride (IV solution) & 2012 & 2.98 & 14.40 & 383.2 & 2.98 & 14.40 & 383.2 \\
\hline $\begin{array}{l}\text { Phenylephrine hydrochloride } \\
\text { (ophthalmic solution) }\end{array}$ & 2013 & 1.68 & 7.50 & 346.4 & - & - & - \\
\hline $\begin{array}{l}\text { Pilocarpine hydrochloride ophthalmic } \\
\text { solution }\end{array}$ & 2012 & 1.94 & 6.20 & 220.4 & - & - & - \\
\hline Potassium chloride oral solution & 2014 & 0.02 & 0.05 & 222.6 & - & - & - \\
\hline Quinine & 2007 & 3.31 & 4.06 & 22.7 & - & - & - \\
\hline Vasopressin & 2014 & 2.18 & 134.20 & $6,069.9$ & 5.13 & 59.40 & $1,057.9$ \\
\hline $\begin{array}{l}\text { aUnit prices are reported, which are per gram, } \\
\text { needed; manufacturer-specific analyses are foct } \\
\text { an approved NDA" in Drugs@FDA. } \\
\text { "There were } 8 \text { drugs for which no pricing data } \\
\text { phosphate injection, colchicine injection, Freshk } \\
\text { trimethobenzamide hydrochloride suppository. } \\
\text { FDA=U.S. Food and Drug Administration; IQ }\end{array}$ & $\begin{array}{l}\text { oer milliliter, or } p \\
\text { sed on the manu } \\
\text { vere available du } \\
\text { ote ophthalmic so }\end{array}$ & $\begin{array}{l}\text { piece (e.g., pil } \\
\text { cturers to whic } \\
\text { ng the } 2 \text { years } \\
\text { tion, otic drug }\end{array}$ & $\begin{array}{l}\text { ecause some } d r \\
\text { he FDA sent UI } \\
\text { re and after } U \\
\text { apain-containi }\end{array}$ & $\begin{array}{l}\text { gs in the sample a } \\
\text { I warning letters o } \\
\text { I regulatory actior } \\
\text { g topical drugs, so }\end{array}$ & $\begin{array}{l}\text { re consumed daily } \\
r \text { that were labele } \\
\text { nor voluntary app } \\
\text { dium nitrite and s }\end{array}$ & $\begin{array}{l}\text {, whereas others } \\
d \text { as previously " } \\
\text { proval: carbinoxan } \\
\text { odium thiosulfate }\end{array}$ & $\begin{array}{l}\text { are taken as } \\
\text { narketed without } \\
\text { mine, codeine } \\
\text { injection, and }\end{array}$ \\
\hline
\end{tabular}

\section{Association Between the UDI and Drug Shortages}

Among the 34 drugs facing UDI action or with a product receiving approval through voluntary compliance, 17 (50.0\%) experienced a shortage in the 2 years before voluntary approval or UDI action, and 25 (73.5\%) experienced a shortage in the 2 years after $(P=0.046)$. Three drugs had a shortage lasting fewer than 7 days and were excluded from the shortage duration analysis. Among the remaining 31 drugs, the median shortage duration in the 2 years before was 31 days (IQR=0-339), whereas in the 2 years after, the duration was 217 days $(\mathrm{IQR}=0-406 ; P=0.053$; Table 4).

\section{Discussion}

We identified 34 previously unapproved prescription drugs that either faced UDI regulatory action or had at least 1 product that received approval after 2006 through manufacturers' voluntary compliance. Among these drugs, prices and shortages increased significantly after UDI action. Specific manufacturers 
The FDA Unapproved Drugs Initiative: An Observational Study

of the Consequences for Drug Prices and Shortages in the United States

TABLE 4 National Drug Shortages of Previously Unapproved Drugs 2 Years Before and After Facing UDI Regulatory Action or Receiving Voluntary Approval ( $N=34)$

\begin{tabular}{|c|c|c|c|c|c|}
\hline & $\begin{array}{c}\text { Year of UDI } \\
\text { Issuance or } \\
\text { Voluntary } \\
\text { Approval }\end{array}$ & $\begin{array}{l}\text { Shortage } \\
\text { Before? }\end{array}$ & $\begin{array}{l}\text { Shortage } \\
\text { After? }\end{array}$ & Shortage Days Before & Shortage Days After \\
\hline Overall, n (\% or IQR) & & $17(50.0 \%)$ & $24(75.0 \%)$ & $31(0-339)$ & $217(0-406)$ \\
\hline$P$ value & & \multicolumn{2}{|c|}{0.046} & \multicolumn{2}{|c|}{0.053} \\
\hline \multicolumn{6}{|l|}{ Drug } \\
\hline Atropine sulfate ophthalmic solution & 2014 & No & Yes & 0 & 406 \\
\hline Balanced salt solution (ophthalmic) & 2008 & No & Yes & 0 & 27 \\
\hline Carbinoxamine & 2006 & No & No & 0 & 0 \\
\hline Codeine phosphate combinations & 2014 & Yes & Yes & 428 & 386 \\
\hline Codeine phosphate injection & 2014 & No & No & 0 & 0 \\
\hline Codeine sulfate tablet & 2009 & No & Yes & 0 & 357 \\
\hline Colchicine injection & 2008 & No & Yes & 0 & $\begin{array}{c}\text { Shortage, number of days } \\
\text { not determinable }\end{array}$ \\
\hline Colchicine tablet & 2010 & Yes & No & 339 & 0 \\
\hline Dihydrocodeine bitartrate combinations & 2014 & No & No & 0 & 0 \\
\hline Epinephrine injection/syringe & 2010 & Yes & Yes & 31 & 564 \\
\hline Ergotamine-containing product & 2007 & No & Yes & 0 & 217 \\
\hline Fluorescein injection & 2011 & Yes & Yes & 147 & 37 \\
\hline Freshkote ophthalmic solution & 2011 & No & No & 0 & 0 \\
\hline Hydrocodone & 2007 & No & Yes & 0 & 310 \\
\hline Hydromorphone injection & 2011 & Yes & Yes & 717 & 628 \\
\hline Hydromorphone tablet & 2009 & No & Yes & 0 & 153 \\
\hline Levothyroxine injection & 2006 & No & Yes & 0 & 383 \\
\hline Morphine sulfate immediate-release tablet & 2009 & Yes & No & 47 & 0 \\
\hline Morphine sulfate injection & 2011 & Yes & Yes & 595 & 730 \\
\hline Morphine sulfate solution & 2009 & Yes & Yes & 39 & 526 \\
\hline Nitroglycerin sublingual tablet & 2010 & Yes & No & 400 & 0 \\
\hline Otic drugs & 2015 & Yes & Yes & 153 & 5 \\
\hline Oxycodone immediate-release tablet & 2009 & Yes & Yes & 82 & 554 \\
\hline Oxycodone solution & 2010 & Yes & Yes & 63 & 405 \\
\hline Pancrelipase & 2004 & No & Yes & 0 & 174 \\
\hline Papain-containing topical drug & 2008 & Yes & Yes & $\begin{array}{c}\text { Shortage, number of days } \\
\text { not determinable }\end{array}$ & 126 \\
\hline Phenylephrine hydrochloride (IV solution) & 2012 & Yes & Yes & 436 & 649 \\
\hline Phenylephrine hydrochloride (ophthalmic solution) & 2013 & No & Yes & 0 & 311 \\
\hline Pilocarpine hydrochloride ophthalmic solution & 2012 & No & Yes & 0 & 129 \\
\hline Potassium chloride oral solution & 2014 & No & No & 0 & 0 \\
\hline Quinine & 2006 & Yes & No & 264 & 0 \\
\hline Sodium nitrite and sodium thiosulfate injection & 2012 & Yes & Yes & 597 & 645 \\
\hline Trimethobenzamide hydrochloride suppository & 2007 & No & Yes & 0 & $\begin{array}{c}\text { Shortage, number of days } \\
\text { not determinable }\end{array}$ \\
\hline Vasopressin & 2014 & Yes & Yes & 730 & 376 \\
\hline
\end{tabular}

that received direct FDA warning letters also were found to have raised prices after obtaining approval for drug products they had already marketed without approval. In addition, all but 2 drugs that received new approval through voluntary compliance or after UDI regulatory action were supported by literature reviews and bioequivalence to older drug products, not new clinical trial evidence. These findings suggest that the UDI had the unintended consequence of increasing drug prices and shortages, while rarely generating additional clinical evidence of safety or efficacy.

Of course, ensuring the safety and efficacy of all marketed drugs is an important FDA responsibility and is essential for 
high-quality patient care. Increasing the FDA's regulatory oversight of previously unapproved drugs allows for it to ensure their safety and effectiveness, conduct regular manufacturing inspections, address confusion due to unregulated trade names through control of labeling, perform constant postmarket surveillance, and promptly publicize emerging safety and efficacy issues. However, our findings suggest that the UDI approval process did not necessarily establish that previously unapproved drugs were more safe or effective than had been understood before the UDI. This may be acceptable, considering that physicians have been using these drugs for decades, but FDA approval can also ensure drug safety through other avenues. For instance, previous FDA approval could have possibly prevented the death of children younger than 2 years from unapproved drug products containing the antihistamine carbinoxamine by reviewing drug labels and prohibiting manufacturer promotion of these drugs to young children. ${ }^{28}$

There are several possibilities that may account for why the UDI was associated with increased drug prices and shortages. First, once the FDA takes regulatory action against manufacturers marketing unapproved drug products, the few manufacturers already marketing approved drug products and the ones able to obtain FDA approval may hold natural monopolies or oligopolies until additional manufacturers obtain approval. Obtaining approval for a subsequent abbreviated NDA for a generic drug manufacturer, however, can be a lengthy process ${ }^{29}$ and manufacturers may instead choose to discontinue unapproved drug products.

Second, when a manufacturer of a previously unapproved drug product receives approval, it can market its product to physicians and payers as more safe and effective than unapproved products that remain on the market from other manufacturers, such as in the case of phenylephrine eye drops; as a result, if competitors have lower sales, they may eventually withdraw from the market. ${ }^{17}$ Third, with new approval, manufacturers may file for patents or receive market exclusivity, thereby barring generic competition, as was the case with colchicine..$^{15}$

All of these scenarios may lead to fewer competitors, wherein prices are more susceptible to increases. ${ }^{20,30}$ Shortages may also ensue if the remaining manufacturers are unable to meet demand..$^{31}$ For example, within 4 months of a manufacturer receiving approval for phenylephrine eye drops, the other 3 manufacturers withdrew from the market, ${ }^{17}$ which was followed soon thereafter by shortages and price increases.

To incentivize manufacturers' voluntary compliance with the UDI, the FDA takes action against other manufacturers of unapproved drugs. ${ }^{4}$ The FDA attempts to balance this incentive with the potential implications for clinical care. When a manufacturer receives approval for a product, the FDA allows a 1-year grace period before taking regulatory action against other manufacturers of unapproved drugs. The grace period can vary based on the expected public health effects of immediate regulatory action on patients; whether the effort to obtain approval was publicly disclosed; and the difficulty in conducting any clinical studies and obtaining approval of a drug product. However, as an example, despite the FDA's efforts, including extending the regulatory action compliance date by 6 years to allow manufacturers of pancrelipase to obtain approval, ${ }^{32}$ shortages of pancrelipase still occurred.

Our findings suggest several ways to mitigate the unintended consequences of the FDA's regulation of unapproved drugs through the UDI. First, the FDA views a short grace period as a way to incentivize manufacturers to be the first to obtain approval of a previously unapproved drug, since it may establish a period of de facto exclusivity for the first manufacturer. ${ }^{4}$ However, grace periods should only be granted when the manufacturer guarantees supply and sets a fair price. Grace periods should also be made longer to allow time for additional manufacturers to obtain approval.

Second, the FDA should consider prioritizing or waiving user fees for applications for previously unapproved drugs to ensure sufficient market competition and drug availability. Third, given that a sufficient number of competitors are needed to ensure low prices and prevent shortages, ${ }^{33}$ the FDA should prioritize applications for multiple competitors. Fourth, similar to when DESI review was performed, the FDA could potentially work with an independent agency, such as the National Institutes of Health, to fund or help manufacturers conduct literature reviews and bioequivalence studies, making it easier for current manufacturers of unapproved drugs to obtain approval and stay in the market. Fifth, because these drugs have been marketed for decades, perhaps existing, rigorously generated real-world evidence could be used to assess their safety and efficacy, in addition to determining how they are used in clinical practice.

Finally, pharmaceutical companies also bear responsibility for the UDI's unintended consequences. Rather than using the UDI as an opportunity to increase prices immediately after obtaining approval for decades-old drugs that they were already marketing without approval, companies should heed former President Barack Obama's call to action on prescription drug costs by working in the interest of public health and pricing drugs fairly. ${ }^{34}$

\section{Limitations}

This study should be considered in the context of some limitations. First, in our calculation of shortage duration, we excluded drugs with shortages of fewer than 7 days because their shortage end date is unknown from the database. Thus, it is not possible to quantify their shortage duration. However, this exclusion likely led to our underestimating the effect of the UDI on drug shortage duration. Drugs with shortages of this length were in shortage since the manufacturer withdrew 
the drug from the market, but we cannot know how long the shortage persisted. Nevertheless, our shortage analysis includes these shortages, since we determined whether any drug shortage took place before and after the UDI.

Second, we presented data on average wholesale prices, which do not account for manufacturer rebates to payers or patients, and data on rebates are not readily available from manufacturers. In addition, pricing data were not consistently available for 8 drug classes, limiting our analysis to 26 drugs. Nevertheless, our analysis on price trends used a robust approach to provide valuable information on the effect of the UDI. For instance, we reported unit prices for each drug (i.e., per gram, per milliliter, or per piece) because some drugs in our sample are consumed daily, whereas others are taken as needed. Then, we focused our analysis on the lowest-priced drug product among each of the 26 drug classes available on the market and only characterized drugs with complete pricing data, without knowing market share. Thus, our analysis is a conservative examination, potentially underestimating the effect of the UDI on average price paid by patients, although even changes of $\$ 0.50$ observed for a drug taken daily amounts to a $\$ 15$ increase over a month.

Third, because this is an observational study, it is possible that changes we observed may have been influenced by factors in addition to the UDI, such as increased demand for the drugs, other legislation or regulatory decisions, or other nonregulatory factors or trends, such as manufacturer product profitability or price competition. Our study was limited by our inability to identify an appropriate control group of drugs that did not face UDI action. As context, drug shortages have increased overall in the past decade. ${ }^{35}$ However, in terms of drug price trends, a recent report found that from 2006 to 2012 , the average generic price for widely used drugs decreased between $7.2 \%$ and $14.5 \%$, while as of 2013 , only $20 \%$ and $10 \%$ of generic drugs faced a price increase of at least $15 \%$ and $50 \%$, respectively. ${ }^{36}$

\section{Conclusions}

The FDA's intention to ensure its oversight of the safety and efficacy of all drugs, including older unapproved drugs, through the UDI is a praiseworthy goal. However, we found that despite the FDA's efforts, there have been unintended consequences of the UDI. The UDI was associated with higher drug prices and more frequent drug shortages, while the approval process for these previously unapproved drugs did not necessarily establish their safety or efficacy based on new clinical trial evidence. As the FDA continues to act against the hundreds of unapproved drug products still marketed in the United States, it should consider careful revision and supplementation of the UDI to ensure that all drugs are not only safe and effective but also affordable and accessible for patients.

\section{Authors}

RAVI GUPTA, MD, Yale University School of Medicine, New Haven, Connecticut. SANKET S. DHRUVA, MD, Robert Wood Johnson Foundation Clinical Scholars Program, Department of Internal Medicine, Yale School of Medicine, New Haven, Connecticut, and Veterans Affairs Connecticut Healthcare System, West Haven, Connecticut. ERIN R. FOX, PharmD, University of Utah Health Care Drug Information Service and Department of Pharmacotherapy, University of Utah College of Pharmacy, Salt Lake City. JOSEPH S. ROSS, MD, MHS, Section of General Internal Medicine and Robert Wood Johnson Foundation Clinical Scholars Program, Department of Internal Medicine, Yale School of Medicine; Department of Health Policy and Management, Yale School of Public Health; and the Center for Outcomes Research and Evaluation, Yale-New Haven Hospital, New Haven, Connecticut.

AUTHOR CORRESPONDENCE: Joseph S. Ross, MD, MHS, P.O. Box 208093, New Haven, CT 06520-8093. Tel.: 203.785.2987; E-mail: joseph.ross@yale.edu.

\section{DISCLOSURES}

This project was not supported by any external grants or funds. Gupta was supported by the Yale University School of Medicine Office of Student Research at the time of this study. Dhruva is supported by the Department of Veterans Affairs as part of the Robert Wood Johnson Foundation Clinical Scholars program. Ross reports receiving research support through Yale University from Johnson and Johnson to develop methods of clinical trial data sharing; from Medtronic and the FDA to develop methods for postmarket surveillance of medical devices; from the FDA to establish the YaleMayo Clinic Center of Excellence in Regulatory Science and Innovation; from the Blue Cross Blue Shield Association to better understand medical technology evidence generation; from the Centers for Medicare \& Medicaid Services to develop and maintain performance measures that are used for public reporting; and from the Laura and John Arnold Foundation to support the Collaboration on Research Integrity and Transparency at Yale. Fox reports travel support from Oklahoma Society of Health System Pharmacists, Premier Oncology Hematology Management Society, and SEHA-United Arab Emirates. Vizient provides some financial support to the University of Utah Drug Information Service to provide summaries of drug shortage information.

Gupta and Ross were responsible for the conception and design of this work, drafted the manuscript, and conducted the statistical analysis. Gupta and Fox were responsible for acquisition of data. Ross provided supervision. All authors participated in the analysis and interpretation of the data and critically revised the manuscript for important intellectual content.

\section{REFERENCES}

1. U.S. Food and Drug Administration. What we do. Available at: http:// www.fda.gov/aboutfda/whatwedo/default.htm. Accessed August 22, 2017.

2. U.S. Food and Drug Administration. Memo re: information provided by the FDA to committee staff re: Drug Efficacy Study Implementation (DESI) program. March 8, 2016. Available at: https://energycommerce.house. gov/sites/republicans.energycommerce.house.gov/files/documents/114/ letters/20160308FDAresponse.pdf. Accessed August 22, 2017.

3. Chhabra R, Kremzner ME, Kiliany BJ. FDA policy on unapproved drug products: past, present, and future. Ann Pharmacother. 2005;39(7-8):1260-64.

4. U.S. Food and Drug Administration. Guidance for FDA staff and industry. Marketed unapproved drugs—compliance policy guide. September 19, 2011. Available at: http://www.fda.gov/downloads/Drugs/ GuidanceComplianceRegulatoryInformation/Guidances/UCM070290.pdf. Accessed August 22, 2017. 
5. U.S. Food and Drug Administration. Drug products containing hydrocodone; enforcement action dates. 72 Fed Regist 55780. October 1, 2007. Available at: http://www.fda.gov/OHRMS/DOCKETS/98fr/E7-19340.pdf. Accessed August 22, 2017.

6. Singer N. Purging the pharmacy of unapproved drugs. The New York Times. March 26, 2010. Available at: http://www.nytimes.com/2010/03/27/ business/27nitroside.html?action=click\&contentCollection=Business\%20Day \&module=RelatedCoverage\&region=Marginalia\&pgtype=article. Accessed September 5, 2017.

7. Singer N. F.D.A. says millions got unapproved heart pills. The New York Times. March 26, 2010. Available at: http://www.nytimes.com/2010/03/27/ business/27nitro.html?mcubz=1. Accessed August 22, 2017.

8. Nasr A, Lauterio TJ, Davis MW. Unapproved drugs in the United States and the Food and Drug Administration. Adv Ther. 2011;28(10):842-56.

9. Karst KR. Marketed unapproved drugs_-past, present and future? FDA Law Blog. February 2007. Available at: http://www.fdalawblog.net/fda_ law_blog_hyman_phelps/files/marketed_unapproved_drugs_feb_07.pdf. Accessed August 22, 2017.

10. Traynor K. FDA approves third pancrelipase product: unapproved products illegal to market after April 28. Am J Health Syst Pharm. 2010;67(10):776

11. Ostroff C, Lee CE, McMeekin J. Unapproved prescription cough, cold, and allergy drug products: recent U.S. Food and Drug Administration regulatory action on unapproved cough, cold, and allergy medications. Chest. 2011;140(2):295-300.

12. Giouroukakis M, Dryer M. Unapproved drugs-the drug information pharmacists' perspective. J Pharm Pract. 2013;26(2):112-19.

13. Gardner TB, Munson JC, Morden NE. The FDA and prescription pancreatic enzyme product cost. Am J Gastroenterol. 2014;109(5):624-25.

14. Guglielmo BJ. The colchicine debacle. JAMA Intern Med. 2013;173(3):184-85.

15. Kesselheim AS, Solomon DH. Incentives for drug development-the curious case of colchicine. N Engl J Med. 2010;362(22):2045-47.

16. Kesselheim AS, Franklin JM, Kim SC, Seeger JD, Solomon DH. Reductions in use of colchicine after FDA enforcement of market exclusivity in a commercially insured population. J Gen Intern Med. 2015;30(11):1633-38.

17. Roach L. The state of generic drugs. EyeNet Magazine. January 2015. Available at: https://www.aao.org/eyenet/article/state-of-generic-drugs. Accessed August 22, 2017.

18. Chen SI, Fox ER, Hall MK, et al. Despite federal legislation, shortages of drugs used in acute care settings remain persistent and prolonged. Health Aff (Millwood). 2016;35(5):798-804.

19. Dusetzina SB. Share of specialty drugs in commercial plans nearly quadrupled, 2003-14. Health Aff (Millwood). 2016;35(7):1241-46.

20. Greene JA, Anderson G, Sharfstein JM. Role of the FDA in affordability of off-patent pharmaceuticals. JAMA. 2016;315(5):461-62.

21. Kesselheim AS, Alpern JD, Stauffer WM. High-cost generic drugsimplications for patients and policymakers. N Engl J Med. 2015;372(7):686.

22. Alpern JD, Song J, Stauffer WM. Essential medicines in the United States-why access is diminishing. N Engl J Med. 2016;374(20):1904-07.
23. U.S. Food and Drug Administration. Compliance actions by drug class. May 15, 2017. Available at: http://www.fda.gov/Drugs/ GuidanceComplianceRegulatoryInformation/EnforcementActivitiesbyFDA/ SelectedEnforcementActionsonUnapprovedDrugs/ucm 238675.htm. Accessed August 22, 2017.

24. U.S. Food and Drug Administration. Drugs@FDA: FDA approved drug products. Available at: https://www.accessdata.fda.gov/scripts/cder/daf/. Accessed August 22, 2017.

25. Truven Health Analytics. Micromedex 2.0 (elecronic version). [Paid access]. Available at: http://www.micromedexsolutions.com. Accessed August 22, 2017.

26. ASHP Expert Panel on Drug Product Shortages, Fox ER, Birt A, et al. ASHP guidelines on managing drug product shortages in hospitals and health systems. Am J Health Syst Pharm. 2009;66(15):1399-406.

27. U.S. Food and Drug Administration. FDA drug shortages. Available at: http://www.accessdata.fda.gov/scripts/drugshortages/default.cfm. Accessed August 22, 2017.

28. Carbinoxamine products; enforcement action dates. A notice by the Food and Drug Administration on 06/09/2006. 71 Fed Regist 33462. June 9, 2006. Available at: https://www.federalregister.gov/documents/2006/06/09/ E6-9033/carbinoxamine-products-enforcement-action-dates/. Accessed August 22, 2017.

29. U.S. Food and Drug Administration. Implementation of the generic drug user fee amendments of 2012 (GDUFA). Testimony of Janet Woodcock before the Senate Committee on Health, Education, Labor, and Pensions. January 28, 2016. Available at: http://www.fda.gov/NewsEvents/Testimony/ ucm484304.htm. Accessed August 22, 2017.

30. Greene JA. Cornering the market on essential drugs. Slate. September 23, 2015. Available at: http://www.slate.com/articles/health_and_science/ medical_examiner/2015/09/generic_drug_price_gouging_how_shkreli_ and_other_monopolists_cornered_the.html. Accessed August 22, 2017.

31. Ventola CL. The drug shortage crisis in the United States: causes, impact, and management strategies. P T. 2011;36(11):740-57.

32. U.S. Food and Drug Administration. Application number: 20725. Summary review. Center for Drug Evaluation and Research. April 30 2009. Available at: http://www.accessdata.fda.gov/drugsatfda_docs/ nda/2009/020725s000SumR.pdf. Accessed August 22, 2017.

33. Gupta R, Kesselheim AS, Downing N, Greene J, Ross JS. Generic drug approvals since the 1984 Hatch-Waxman Act. JAMA Intern Med. 2016;176(9):1391-93.

34. Obama B. United States health care reform: progress to date and next steps. JAMA. 2016;316(5):525-32.

35. U.S. Food and Drug Administration. Strategic plan for preventing and mitigating drug shortages. October 2013. Available at: https://www.fda. gov/downloads/drugs/drugsafety/drugshortages/ucm372566.pdf. Accessed August 22, 2017.

36. Schondelmeyer SW. Why are some generic drugs skyrocketing in price? Statement before Senate Committee on Health, Education, Labor and Pensions. November 20, 2014. Available at: http://www.help.senate.gov/imo/ media/doc/Schondelmeyer.pdf. Accessed August 22, 2017. 